\title{
Influence of Salinity and Temperature on Germination of Trifolium repens
}

\author{
Morteza Saberi ${ }^{1}$, Mohammad Reza Dahmardeh Ghaleno ${ }^{1}$, Mojtaba Solaimani Sardo ${ }^{2} \&$ Farajollah Tarnian $^{3}$ \\ ${ }^{1}$ Faculty of Natural Resources, University of Zabol, Iran \\ ${ }^{2}$ M.Sc. student of Aridzone Management, Gorgan University of Agriculture and Natrual Resorces, Iran \\ ${ }^{3}$ Graduated M.Sc. Student of Range Management, University of Tehran, Karaj, Iran \\ Correspondence: Morteza Saberi, Faculty of Natural Resources, University of Zabol, Iran. Tel: \\ 98-91-5954-4760. E-mail: m_saberi63@yahoo.com
}

Received: January 12, 2012

Accepted: August 18, $2012 \quad$ Online Published: August 24, 2012

doi:10.5539/mas.v6n9p34

URL: http://dx.doi.org/10.5539/mas.v6n9p34

\begin{abstract}
In this study, germination character and growth of Trifolium repens were studied by using a completely randomized design with four replications at two levels of temperature regime $\left(25^{\circ} \mathrm{C}\right.$ and $\left.35^{\circ} \mathrm{C}\right)$ and at five levels of salinity (distilled water, 3,6 and $12 \mathrm{ds} / \mathrm{m}$ ). The results of variance analysis showed that the different levels of salinity and temperature were highly significance on germination percentage, germination speed, length of root and length of shoot $(\mathrm{p}<0.01)$. Germination percentage showed that rate of germination decreased with an increase in salinity. Maximum germination speed, root length, and shoot length was related to $25^{\circ} \mathrm{C}$ temperature and control treatment and minimum of these character was belong to $5^{\circ} \mathrm{C}$ and $12 \mathrm{ds} / \mathrm{m}$ salinity. In both of two levels of temperature treatment $\left(25\right.$ and $\left.35^{\circ} \mathrm{C}\right)$ differences between shoot length and root length was less by increasing in salinity levels.
\end{abstract}

Keywords: saline stress, seed germination, temperature regime, Trifolium repens

\section{Introduction}

Salinity is one of the essential osmotic stresses that limits growth and production of plant (Puresmaeal et al., 2005). Salinity damages in plants by the way of osmotic effect are for their poisonous effect belongs to ions and derangement in absorbing of food elements (Safarnejad \& Hamidi, 2005; Ajmal khan et al., 2000; Joshi et al., 2004). The existed salt in soil causes potential decrease of water in growth environment of root and limits the absorption of it by root (Mauromicale \& Licandro, 2002). Consequently, plant to be involved in a kind of physiological dryness. Most of reports indicate that salinity causes intense decrease of production of dry material of plants. Different levels of salinity can decrease photosynthesis and increase viscosity of sodium, chlorine in plant. Salinity also can cause absence some proteins and enzymes. Therefore, endurance of salinity in germination level has special importance (Karimi et al., 2004). Salinity is one case that abates potential of water at environment of root because of potential decrease of accessible water for plant and another case is some ions have poisonous effect on physiological and biochemical processes of plant that both of these two problems cause disorder in absorption of food agents by root and ultimately lead to decreasing in growth of plant (Fenando et al., 2000) and sensitivity of plants to saltiness contrasts in different levels of growth (Maghtoli \& chaichi,1999; Maibody \& Gharehreyazi, 2002). So that, Shanon (1984) stated that in most of plants, the most sensitivity level in period of plant life to salinity are the stages of budding and flowering. Whereas Grime and Campbell (1991) knew the most sensitivity of plants to salinity is at time of seed germination and beginning of embryos growth. Stone et al. (1979) announced that medicago in the beginning stages of growth is more sensitive to salinity and there is a reciprocal influence between levels of saltiness to percentage of seed germination. Thus, the results of Flower (1991) showed that the germination percentage reduction of crambe abyssinica reach to a maximum temperature of $30^{\circ} \mathrm{C}$ by increasing salinity and time. Whereas in temperatures of 15 and $25^{\circ} \mathrm{C}$, salinity has no important influence on decreasing of germination percentage. Gulzar et al. (2001) also reported that germination of Urochondra Setulosa abated with advancing of Salinity and temperature so that decreasing of germination percentage at 25 and $35^{\circ} \mathrm{C}$ in compare with 15 and $20^{\circ} \mathrm{C}$ was more visible. Guma et al. (2010) stated that germination percentage and germination rate of Salsola vermiculata decreased with an increase in temperature and $\mathrm{NaCl}$ concentration. The higher 
percentages wereobtained at $10-20^{\circ} \mathrm{C}$ in seeds exposed to 0 and $200 \mathrm{mM} \mathrm{NaCl}$. Xue et al. (2012) also investigated influence of salinity and temperature on the germination of Hedysarum scoparium. They stated that Germination was inhibited above or below the optimal temperature of $15^{\circ} \mathrm{C}$. The highest germination percentages were under non-saline conditions, and increased $\mathrm{NaCl}$ concentrations progressively inhibited seed germination. Germination rate decreased with increased salinity at all temperatures, but the highest rates were at $15^{\circ} \mathrm{C}$. In Argania spinosa is cleared that there are determined difference between levels of salt from the points of germination rate, length of root and dry weight and there is no delay with advancing of salt viscosity in beginning time of germination of this plant but from rate of germination and length of root and dry weight of radical decrease (Aameur \& Siple-Michmer-huizen, 2001).

White clover is a perennial plant and has permanent roots in soil that the long of them reach to 1 meter. Additional roots exit from joint and knots of stems where they contact with soil. Stems of this species of clover are hollow and they creep on ground. This clover in contrary to red clover has fewer requirements to all conditions of growth. One of important benefits of this herb is the ability of planting of it with seeds of ordinary lawn.

In regions that it is common the creation of artificial pastures and or in dry zones for example Iran has natural and narrow pastures. By considering mentioned subjects and because there is absence of minute knowledge in relation to different pastoral types resisted to different salty degrees it is essential that expanded studies take place on this topic until with better knowledge can be chosen the resistance types to salinity for creating a plan cover.

So, the aim of this research is mentioned to resistance of (Trifolium repens) to salinity by regarding to germination factors in laboratory condition.

\section{Materials and Methods}

It has studied reaction of germination of white clover plant to different levels of salinity in result of $\mathrm{NaCl}$ and two temperature levels during a laboratory consideration.

This test performed in form of factorial that had salinity treatment with five levels $(0,3,6,9,12 \mathrm{ds} / \mathrm{m})$ and two heat levels $\left(25,35^{\circ} \mathrm{C}\right)$ with four replications. Every replication involves one Petri dish with dimensions of $10 \times 10 \mathrm{~m}^{2}$ and 25 seeds.

Seeds place in $\mathrm{HiPoNaCl}$ solution of 2.5 percent for 5 minutes and then washed them with distilled water for three times and placed them between two layers of filter paper (Watman No.1). To every Petri dish added 5 millimeters of produced salinity solution and placed them at 25 and $35^{\circ} \mathrm{C}$ into growth rooms.

Salinity solution of every Petri dish changed every two days for keeping the salinity viscosity of Petri dishes and germinated seeds were counted every day. Then percentage and speed of germination, root length and shoot length were measured after 7 days of beginning of test.

1) Percentage of germination. It is calculated of numbers of budding seeds divided into numbers of all of seeds multiplied by 100 (Khosh-Khui, 2005; Camberato \& Mccarty, 1999; Hartmann \& Kester, 1983).

$\mathrm{GP}=\left(\sum \mathrm{G} / \mathrm{N}\right) * 100$

GP: germination percentage

G: numbers of budding seeds

$\mathrm{N}$ : numbers of all seeds

2) Speed of germination. It is calculated on numbers of budding seeds in every day according to formula (Walker, 1990).

$$
\text { Germination speed }=\sum \frac{F i \times n i}{N}
$$

Fi: counting day

ni: number of budding seeds on that day

$\mathrm{N}$ : total budding seeds on basis of seed/ day

The collected data were analyzed using MSTAT-C and mean comparison was performed using Duncan's multiple range test. 


\section{Results}

Results of variance analysis showed that there is a significant difference between salinity treatments in regarding to percent and speed of germination, root length and shoot length $(\mathrm{p}<0.01)$. Also, there is a significant difference between two temperature level in regarding to their percentage and germination speed, root length and shoot length (Table 1).

Table 1. Variance analysis effect of temperature and saltiness on specialty of Trifolium repens

\begin{tabular}{ccccc}
\hline $\mathrm{F}$ & $\mathrm{ms}$ & $\mathrm{df}$ & Source of variable & factor \\
\hline $102.413^{* *}$ & 1488.4 & 1 & Temperature & \\
$619.995^{* *}$ & 9010.6 & 4 & Saltiness & germination(\%) \\
$10.142^{* *}$ & 147.4 & 4 & Temperature and Saltiness & \\
--- & 14.533 & 30 & Error & Germination \\
\hline $65.472^{* *}$ & 20.449 & 1 & Temperature & speed(seed.day) \\
$461.937^{* *}$ & 144.287 & 4 & Saltiness & \\
$15.423^{* *}$ & 4.817 & 4 & Temperature and Saltiness & \\
--- & 0.312 & 30 & Error & Rootlength(cm) \\
\hline $44.841^{* *}$ & 2.555 & 1 & Temperature & \\
$205.570^{* *}$ & 11.717 & 4 & Saltiness & \\
$2.092^{\text {ns }}$ & 0.119 & 4 & Temperature and Saltiness & \\
$===$ & 0.057 & 30 & Error & Shoot length $(\mathrm{cm})$ \\
\hline $41.789^{* *}$ & 3.364 & 1 & Temperature & \\
$179.06^{* *}$ & 14.414 & 4 & Saltiness & \\
$1.486^{\text {ns }}$ & 0.12 & 4 & Temperature and Saltiness & \\
$===$ & 0.08 & 30 & Error & \\
\hline
\end{tabular}

**meaningful differences between treatment at $1 \%$ level. ns: non-significant difference between treatments.

\section{Saltiness}

In considering of salinity act on Trifolium repens showed that by increasing of salinity level, the rate of germination, germination speed, root and shoot length decreases (Table 2). While the level of salinity goes the head so control treatment reach to level of $12 \mathrm{ds} / \mathrm{m}$ and germination percentage decreased from 92 to 12.5 percent. Studying the speed of germination illustrated that speed germination of the species under studying abates with increasing the level of saltiness in some way control level $12 \mathrm{ds} / \mathrm{m}$. Also, results of this consideration shows that by advancing of saltiness level causes a reduction in root length and shoot length. It has been significant difference in root length and shoot length between different levels of salinities but it is not significant difference of root and shoot length between salinity levels of 9 and $12 \mathrm{ds} / \mathrm{m}$. So that according to results of Duncan's test these two root and shoot length placed into a (d) group in these two levels of salinity (Table 2).

Table 2. Average comparison effect of saltiness on specialty of Trifoliumrepens

\begin{tabular}{ccccc}
\hline $\begin{array}{c}\text { Shoot } \\
\text { length }(\mathrm{cm})\end{array}$ & $\begin{array}{c}\text { Root } \\
\text { length }(\mathrm{cm})\end{array}$ & $\begin{array}{c}\text { germination } \\
\text { speed(seed.day) }\end{array}$ & germination(\%) & $\begin{array}{c}\text { Salinity } \\
(\mathrm{ds} / \mathrm{m})\end{array}$ \\
\hline $2.72^{\mathrm{a}}$ & $2.1^{\mathrm{a}}$ & $10.85^{\mathrm{a}}$ & $92^{\mathrm{a}}$ & 0 \\
$2.62^{\mathrm{b}}$ & $2.168^{\mathrm{b}}$ & $10.05^{\mathrm{b}}$ & $85^{\mathrm{b}}$ & 3 \\
$1.77^{\mathrm{c}}$ & $1.175^{\mathrm{c}}$ & $9.21^{\mathrm{c}}$ & $77.5^{\mathrm{c}}$ & 6 \\
$0.68^{\mathrm{b}}$ & $0.269^{\mathrm{d}}$ & $4.42^{\mathrm{d}}$ & $42^{\mathrm{d}}$ & 9 \\
$0.55^{\mathrm{d}}$ & $0.275^{\mathrm{d}}$ & $0.95^{\mathrm{e}}$ & $12.5^{\mathrm{e}}$ & 12 \\
\hline
\end{tabular}

Significant differences indicated by different letter $(\mathrm{P}<0.05)$. 


\section{Temperature}

Results of temperature illustrated that germination percentage, germination speed, root length and shoot length decreased by increasing temperature from 25 to $35^{\circ} \mathrm{C}$ that there was a meaningful difference between all properties under studying in two temperature level $\left(25\right.$ and $\left.35^{\circ} \mathrm{C}\right)(\mathrm{p}<0.01)$. by advancing of heat up to 10 degrees, rate of germination percentage diminished to $8 / 2$ percent and speed of germination diminished to $1 / 51$ (seed in a day). Also, by increasing of heat from 25 to $35^{\circ} \mathrm{C}$, root length and shoot length decrease 31 and $27 \%$.

\section{Temperature and Salinity}

The mutual effect of temperature and salinity showed that there was significant difference among the germination percentage of Trifolium repens $(\mathrm{p}<0.01)$ (Figure 1). Also, by comparison of germination percentage in different levels of temperature and salinity showed that it is observable the highest rate of germination in control treatment is at $25^{\circ} \mathrm{C}(98 \%)$ and the lowest rate is at $12 \mathrm{ds} / \mathrm{m}$ and $35^{\circ} \mathrm{C}$ heat $(8 \%)$. The germination speed of Trifolium repens deceased in two temperatures by increasing of salinity levels so that there were significant differences between germination speed in two temperatures at 3 and $6 \mathrm{ds} / \mathrm{m}$ salinity levels and control but there were not significant differences between germination speed in two temperatures at $9,12 \mathrm{ds} / \mathrm{m}$ salinity levels. The highest speed of germination observed at $25^{\circ} \mathrm{C}$ and $3 \mathrm{ds} / \mathrm{m}(11.7 \mathrm{seed}$ per day $)$ (Figure 2).

Results of root and shoot length of Trifolium repens illustrated that by advancing of temperature and salinity level, the length of root and shoot decreased intensively. The highest length of root in relation with control treatment has been in heat of $25^{\circ} \mathrm{C}(3.5$ centimeters) and the lowest of it in relation with salinity level of 12 $\mathrm{ds} / \mathrm{m}$ has been in heat of $35^{\circ} \mathrm{C}(0.15$ centimeter $)$. Also, the highest shoot length in control treatment has observed in temperature of $25^{\circ} \mathrm{C}$ ( 4 centimeters) and lowest of it in salinity surface of $12 \mathrm{ds} / \mathrm{m}$ has been in heat of $35^{\circ} \mathrm{C}(0.32$ centimeters $)$. In both of 25 and $35^{\circ} \mathrm{C}$ temperatures length of root and shoot reached to lowest quantity at salinity level of $12 \mathrm{ds} / \mathrm{m}$. (Figures 3 and 4 )

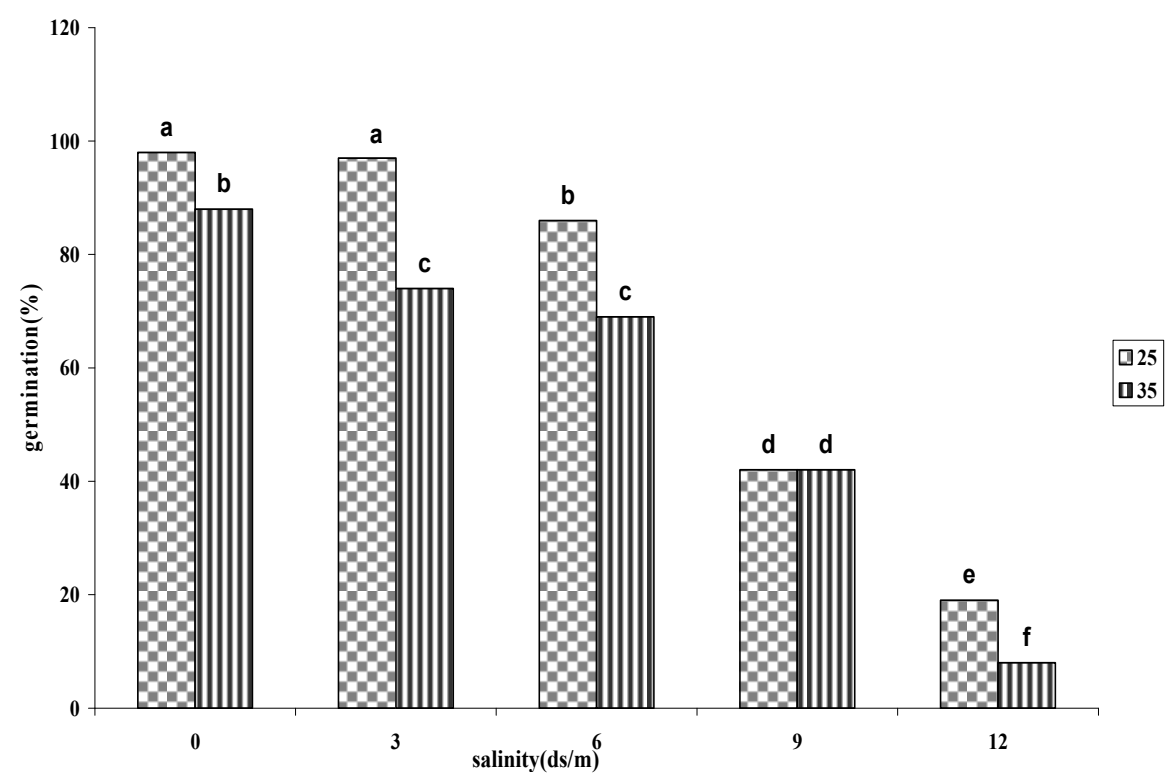

Figure 1. Germination percentage of Trifolium repens in different levels of Temperature and salinity. Significant differences indicated by different letter $(\mathrm{P}<0.05)$ 


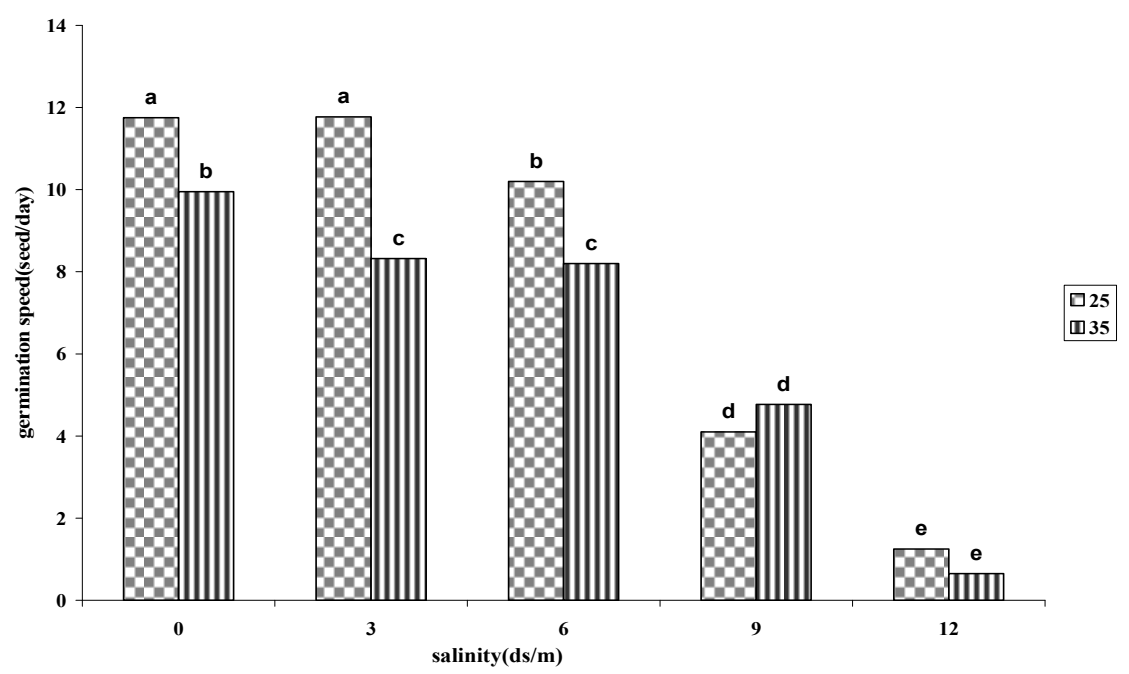

Figure 2. Germination speed of Trifolium repens in different levels of temperature and salinity. Significant differences indicated by different letter $(\mathrm{P}<0.05)$

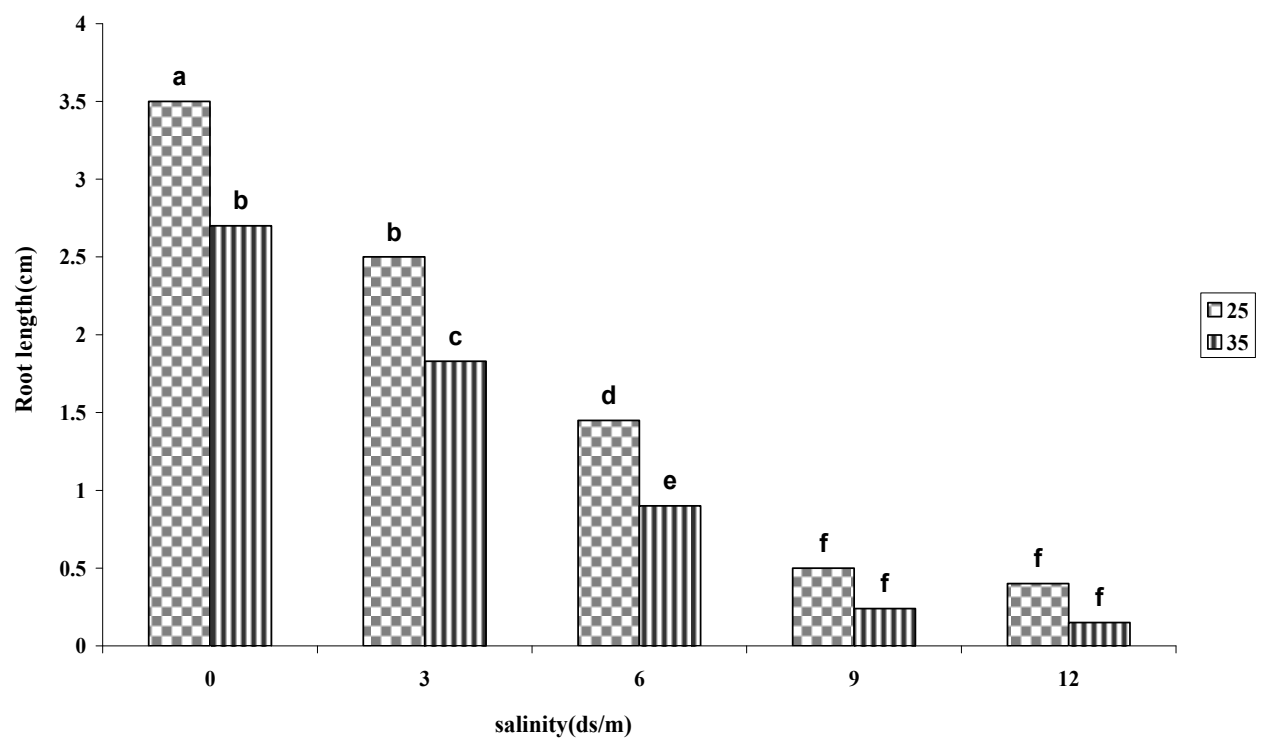

Figure 3. Root length of Trifolium repens in different levels of temperature and salinity. Significant differences indicated by different letter $(\mathrm{P}<0.05)$ 


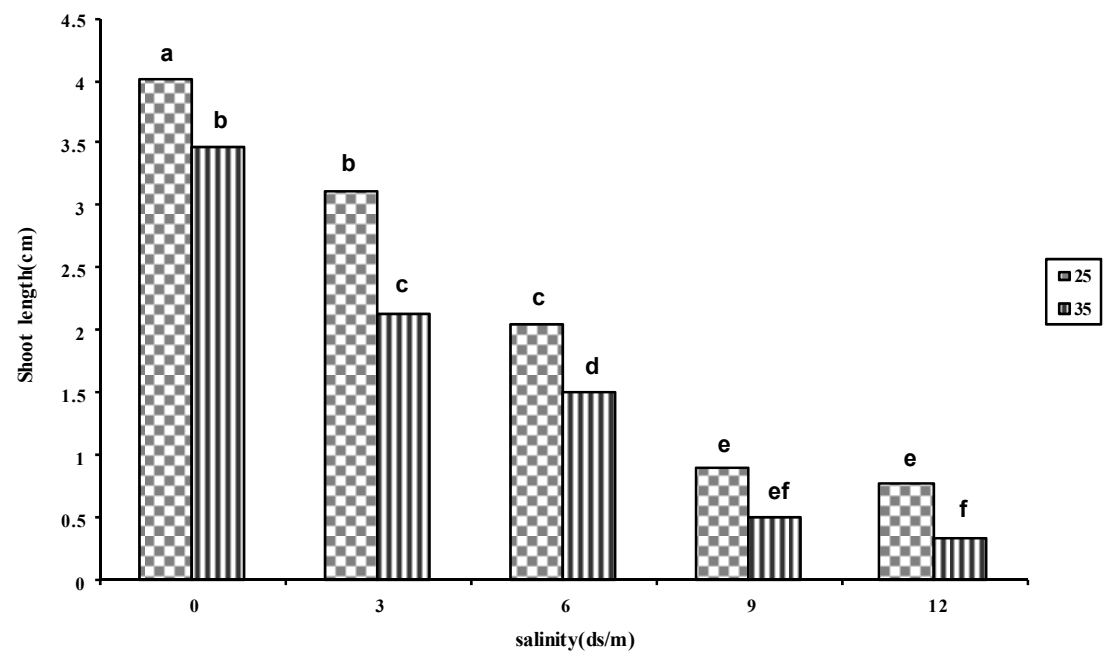

Figure 4. Shoot length of Trifolium repens kind in different levels of temperature and salinity. Significant differences indicated by different letter $(\mathrm{P}<0.05)$

\section{Discussion and Conclusion}

The main factors that effect on plant types growth of arid and semiarid areas are high environmental temperature and high salinity. Studying of Trifolium repens clarified that germination percentage, germination speed, root length and shoot length have reduced with increasing of temperature and salinity.

Decreasing of germination rate in relation with advancing of salinity has connected to decrease absorption of water and to increase the ions and then it cause water stress by osmotic balance (Dotzenko \& Dean, 1959). By going up of ions that are affected by advancing of salts viscosity and this makes a poisonous ion, so germination of Trifolium repens has decreased (Rajabi \& Postini, 2005; Fenando et al., 2005; Safarnejad \& Hamidi, 2005; Shalhevet, 1993). The rate of germination speed of Trifolium repens has decreased by advancing of temperature and salinity levels. Existence of cations and decreasing of water potential of plant are the reasons for decreasing of germination speed that are in connection with advancing of salinity. Consequently, plant cannot absorb water for decreasing of water potential and faces with shortage of water (Singh et al., 1988; Farah Khah et al., 2004). This process intensifies with advancing of temperature level. Results of this study illustrate that advancing of temperature and salinity had affection on decreasing of root length and shoot length. The cause of decreasing in root and shoot length in high levels of $\mathrm{NaCl}$ is for negative effects of $\mathrm{NaCl}$ on cell membrane and creation of poisonous ion (Bal \& Chattopahyay, 1985) and spoiling of cytoplasm membrane (Khan \& Ungar, 1998; Azarinvand \& Jafarian, 2004). NaCl Also has deranged the action of some affective enzymes in plant and by this way decreases the length of root and shoot. Farah khan et al. (2002) and Hardegree and Emmeric (1990) have mentioned to this question in their studies.

Perfectly results of this study showed that rate of germination, speed of germination, length of root and shoot of Trifolium repens are decreased by increasing of temporal and salinity levels for creating disorder in subsistence process of Trifolium repens. Destructive influence of $\mathrm{NaCl}$ that are aggravated with increasing of its viscosity cause disarrangement of plant cell wall so the properties under study be affected and it cause long average time of germination and slow speed of germination the seeds and decrease in growth of root and shoot length. Over all, it is not suggested to plant this species in areas with high salinity (more than $6 \mathrm{ds} / \mathrm{m}$ ) because it is not economical to plant Trifolium repens in lands with high salts viscosity.

\section{References}

Aameur, F., \& Sipple-Michmer-huizen, J. (2001). Germination and seedling survival of Argan (Arganiaspinosa) under experimental saline condition. Journal of Arid Environments, 49, 533-540.

Azarnivand, H., \& Jafarian, Z. (2004). The effect of salinity on seed germination of Agropyron desertorum and Agropyron cristatium. Desert (Biaban), 8(1), 52-62. http://dx.doi.org/10.1007/BF02894635

Bal, A. R., \& Chattopahyay, N. C. (1958). Effect of Nacl and PEG 6000 on germination and seedling growth of rice (Oryza sativa L.). BiologiaPlantarum, 27, 65-69. 
Camberato, J. D., \& Mccarty, B. (1999). Irrigation water quality: part 1. Salinity. South Carolina Turfgrass Foundation New, 6(2), 6-8. http://dx.doi.org/10.2134/agronj1959.00021962005100050019x

Dotzenko, A. D., \& Dean, J. G. (1959). Germination of six alfalfa variation on the three levels of osmotic pressure. Agron. J., 51, 308-309.

Farah khah, A., HeydarisharifAbad, H., Ghorban Ali, M., \& Shakerbazarno, H. (2004). The effect of saltiness on germination of three species: Aeluropus lagopoides and Alhagi persarum, salsola dendroides. Genetic researches and probe chapter letter and reform of pasture and forest plants of Iran, 1-3(1), 11.

Fenando, E. P., Boero, C., Gallaro, M., \& Gonzales, J. (2000). Effect of Nacl on germination, growth, and soluble sugar content in Chenopodium quinona seeds. Bot. Bull. Acad. Sin., 41, 27-34.

Flower, J. L. (1991). Interacteion of salinity and temperature on germination of Crambe. Agronomy Journal, 83, 169-172. http://dx.doi.org/10.2134/agronj1991.00021962008300010039x

Grime, J. P., \& Campbell, B. D. (1991). Growth rate. Habitat productivity, and plant strategy as predicators of stress responses. In: Mooney, H. A.; W. E. Winner.; Ee. J. Pell.; and chu, E.(eds): Response of plants to Multiple stresses pp: 143-159. San Diego, Academic press; London, UK; pp 422.

Gulzar, S., Khan, M. A., \& Ungar, A. (2001). Effect of salinity and temperature on the germination of Urochondra setulosa (Trin). Seed science and Technology, 29, 21-29. Retrieved from www.halophyte.org/pdfs/drkhan_pdfs/50.pdf

Guma, I. R., Padron-Mederos, M. A., Santos-Guerra, A., \& Reyes-Betancort, J. A. (2010). Effect of temperature and salinity on germination of Salsola vermiculata L. (Chenopodiaceae) from Canary Islands. Journal of Arid Environments, 74, 708-711. http://dx.doi.org/10.1016/j.jaridenv.2009.10.001

Hardegree, S. P., \& Emmeric, W. E. (1990). Partitioning water potential and specific salt effect on seed germination of four grasses. Annual of Botany, 65, 585-587. Retrieved from http://aob.oxfordjournals.org/content/66/5/587.abstract

Hartmann, H. T., \& Kester, D. E. (1983). Plant propagation: principles and practice. New Jersey: Prentice Hall.

Joshi, A. J., Mali, B. S., \& Hinglajia, H. (2004). Salt tolerance at germination and early growth of two forage grasses growing in marshy habitats. Environmental and experimental botany, 154-160. http://dx.doi.org/10.1016/j.envexpbot.2004.09.005

Karimi, Gh., Heydari SharifAbad, H., \& Asareh, M. H. (2004). The effects of saltiness stress on germination, planted and Prolin containing Atriplex verrucifera. Genetic research and prob chapter letter and reform of pasture and forest plants of Iran, 432(4), 12.

Khan, M.A., Gul, B., \& Weber, D.J. (2000).Germination responses of Salicorniarubra to temperature and $\begin{array}{llll}\text { salinity. Journal of Arid } & \text { Environmentes, }\end{array}$ http://dx.doi.org/10.1006/jare.2000.0640http://dx.doi.org/10.1006/jare.2000.0640

Khan, M., \& Ungar, I. A. (1998). Germination of salt tolerant shrub Suaeda fruticosa from Pakistan: salinity and temperature responses. Seed Science and Technology, 26, 657-667. Retrieved from http://cat.inist.fr/?aModele=afficheN\&cpsidt $=1746597$

Khosh-Khui, M. (2005). Plant ptopagation: Principle and practices (translated in Persian). Shiraz univ. Press, pp 983. (Translate in Persian).

Maghtoli, M., \& Chaichi, M. (1999). Effect of salinity and salt type on germination and early growth of sorghum. Journal of Agriculture science and natural Resources, 4, 33-40.

Maibody, S. A. M., \& Gharehreyazi, B. (2002). Physiological aspects and breeding for salinity stress in plants. Isfahan University of technology press, p. 274.

Mauromicale, G., \& Licandro, P. (2002). Salinity and temperature effects on germination, emergence and seedling growth of global Artichoke. Agronomy, 22, 443-540. http://dx.doi.org/10.1051/agro:2002011

Puresmaeal, M., Ghorban Ali, M., \& Khavarinejad, R. (2005). The effect of saltiness on germination, dry and wet weight, ion containing, Prolin, Solution sugar and plant starch suaeda fruticosa. Dessert magazine, 257-264(2), 10.

Rajabi, R., \& Postini, K. (2005). Effect of Nacl on thirty cultivars of bread wheat seed germination. Agriculture Science Journal, 27(1), 29-45. 
Safarnejad, A., \& Hamidi, H. (2005). Effect of saltiness clash on germination and growth of some of drug plants, plant permanent extension international congress, Mashhad.

Shalhevet, J. (1993). Plant under salt and water stress. In: plant adaptation to environmental stress, 133-154. Chaoman and Hall.

Shanon, M. C. (1984). Breeding, Selection, Salinity tolerance in plants.John wiley and sons.

Singh, K. N., Sharma, D. K., \& Chillar, R. K. (1988). Growth, yield and chemical composition of different oil seed crop as influenced by sodicity. The Journal of Agricultural Science, 3, 459-463.

Stone, J. E., Marx, D. B., \& Dobrenz, A. K. (1979). Interaction of sodium chloride temperature on germination of two alfalfa cultivars. Agronomy Journal, 71, 425-427. http://dx.doi.org/10.2134/agronj1979.00021962007100030011x

Xue, J. G., Wang, X. G., Du, X. G., Mao, P. S., Zhang, T. J., Zhao, L., \& Han, J. G. (2012). Influence of salinity and temperature on the germination of Hedysarum scopariumFisch. etMey. African Journal of Biotechnology, 11(14), 3244-3249. http://dx.doi.org/10.5897/AJB10.2069 